\title{
Pola Distribusi Hujan Kota Surabaya
}

\author{
S. Kamilia Aziz, Ismail Sa'ud \\ Program Studi Diploma Teknik Sipil FTSP ITS \\ Email: kamiliaharis@gmail.com
}

\begin{abstract}
Surabaya city experienced rain in certain months. Of rainfall data from rainfall data known to the average height of rainfall occurs in December-January. While low rainfall occurs in July-September. Because of this Surabaya there are 11 stations that are placed scattered rain, then rain recorded at each station may not be the same. The aim of this study is to obtain a pattern/picture of rainfall distribution and intensity of rainfall plan that goes with return period of 2 years, 5 years and 10 years. Benefit from this study that can be used as a starting point in planning the drainage system in the development of the area in Surabaya. The results obtained are of the pattern of rain intensity plans 2 years, 5 years and 10 years showed the greater period, the smaller the density repeated isohyetnya line. The rainfall intensity return period of 2 years, 5 years occurred in Simo Station at $28 \mathrm{~mm} / \mathrm{hour}$ and 40 $\mathrm{mm} /$ hour, while the 10-year return period occurred in Wonorejo Station is $47 \mathrm{~mm} / \mathrm{hour}$. The smallest rainfall intensity return period of 2 years, 5 years, and 10 years occurred in Kedung Cowek Station at $15 \mathrm{~mm} / \mathrm{hour}, 26 \mathrm{~mm} / \mathrm{hour}$, and $33 \mathrm{~mm} / \mathrm{hour}$. Based districts greatest rainfall intensity return period of 2 years, 5 years occurred in Sawahan and a return period of 10 years occurred in the District Rungkut. While the smallest rainfall intensity return period of 2 years, 5 years, and 10 years occurred in the District Kenjeran.
\end{abstract}

Keyword: surabaya, pattern, intensity, isohyet.

Abstrak

Kota Surabaya mengalami hujan pada bulan-bulan tertentu. Dari data curah hujan diketahui curah hujan tinggi terjadi pada bulan Desember- Januari. Sedangkan curah hujan rendah terjadi pada bulan Juli - September. Karena di Surabaya ini terdapat 11 stasiun hujan yang ditempatkan secara terpencar, maka tinggi hujan yang tercatat pada masing-masing stasiun tidak sama. Tujuan dari studi ini yaitu untuk mendapatkan suatu pola/gambaran penyebaran hujan rencana dan intensitas hujan yang terjadi dengan periode ulang 2 tahun, 5 tahun, dan 10 tahun. Manfaat dari studi ini yaitu bisa dijadikan acuan awal dalam perencanaan sistem drainase di pengembangan wilayah di Kota Surabaya. Hasil yang didapatkan yaitu dari pola intensitas hujan rencana 2 tahun, 5 tahun dan 10 tahun menunjukkan semakin besar periode ulangnya maka semakin kecil kerapatan garis isohyetnya. Intensitas hujan yang terbesar periode ulang 2 tahun, 5 tahun terjadi di Stasiun Simo sebesar $28 \mathrm{~mm} / \mathrm{jam}$ dan $40 \mathrm{~mm} / \mathrm{jam}$, sedangkan periode ulang 10 tahun terjadi di Stasiun Wonorejo sebesar $47 \mathrm{~mm} / \mathrm{jam}$. Intensitas hujan yang terkecil periode ulang 2 tahun, 5 tahun, dan 10 tahun terjadi di Stasiun Kedung Cowek sebesar 15 mm/jam, 26 mm/jam, dan 33 $\mathbf{m m} / \mathbf{j a m}$. Berdasarkan wilayah kecamatan Intensitas hujan yang terbesar periode ulang 2 tahun, 5 tahun terjadi di Kecamatan Sawahan dan periode ulang 10 tahun terjadi di Kecamatan Rungkut. Sedangkan intensitas hujan yang terkecil periode ulang 2 tahun, 5 tahun, dan 10 tahun terjadi di Kecamatan Kenjeran.

Kata kunci: Surabaya, pola, intensitas, isohyet.

\section{Pendahuluan}

Kota Surabaya mengalami hujan pada bulan-bulan tertentu. Dari data curah hujan diketahui curah hujan tinggi terjadi pada bulan Desember-Januari. Sedangkan curah hujan rendah terjadi pada bulan Juli-September. Tinggi curah hujan dinyatakan dalam satuan milimeter (mm). $1 \mathrm{~mm}$ memiliki arti

bahwa dalam suatu area dengan luas 1 $\mathrm{m}^{2}$ memiliki air dengan tinggi $1 \mathrm{~mm}$ dengan keadaan air tidak menguap dan tidak mengalir. Sehingga sama saja dengan volume air sebesar 1 liter di suatu area dengan luas $1 \mathrm{~m}^{2}$.

Dalam studi ini digunakan 11 stasiun hujan, yaitu Gubeng, Gunungsari, 
Kandangan, Kebon Agung, Kedung Cowek, Keputih, Larangan, Perak, Simo, Wonokromo, dan Wonorejo. Semua stasiun tersebut terdapat alat ukur hujan baik manual maupun otomatis yang diamati oleh pengamat lapangan dan tinggi hujannya dicatat. Stasiun penakar hujan hanya memberikan kedalaman hujan di titik dimana stasiun berada, sehingga hujan pada suatu luasan harus diperkirakan dari titik pengukuran tersebut. Karena di Surabaya ini terdapat 11 stasiun hujan yang ditempatkan secara terpencar, maka hujan yang tercatat di masing-masing stasiun dapat tidak sama.

Tujuan dari studi ini yaitu untuk mendapatkan suatu pola/ gambaran penyebaran hujan rencana dan intensitas hujan yang terjadi dengan periode ulang 2 tahun, 5 tahun, dan 10 tahun. Dari hasil studi ini juga mendapatkan besarnya hujan rencana dan intensitas hujan di setiap kecamatan di Kota Surabaya. Manfaat dari studi ini yaitu bisa dijadikan acuan awal dalam perencanaan sistem drainase di pengembangan wilayah di Kota Surabaya.

\section{Metodologi}

Langkah pertama dalam penelitian ini adalah pengumpulan data curah hujan semua stasiun hujan dari tahun 1973 sampai tahun 2014 dan peta Kota Surabaya. Data lokasi stasiun hujan kemudian diplot di peta Kota Surabaya berdasarkan data koordinat setiap stasiun. Untuk mempermudah pekerjaan ploting lokasi stasiun hujan ke peta
Kota Surabaya digunakan program bantu Auto Cad yang berkoordinat UTM (Universal Transverse Mercator) dan skala gambar peta Kota Surabaya disesuaikan dengan kenyataan di lapangan. Sistematika penyelesaian studi ini berdasarkan teori yang ada disusun sebagai berikut:

\subsection{Pemilihan Hujan Maksimum}

Dari data yang sudah dikumpulkan kemudian dilakukan pemilihan tinggi hujan maksimum di waktu/ hari yang sama di setiap tahun. Dari data hujan maksimum dilakukan pelengkapan/ pengisian data hujan yang hilang jika terdapat data hujan yang tidak lengkap. Metode yang digunakan yaitu inversed square distance, dimana data hujan yang hilang di suatu stasiun hujan tersebut dihitung berdasarkan jarak dan tinggi hujan stasiun yang bersangkutan dengan beberapa stasiun hujan di sekeliling stasiun yang bersangkutan.

$P X=\frac{\frac{1}{a^{2} \cdot P A+\frac{1}{b^{2}} \cdot P B+\cdots \frac{1}{n^{2}} \cdot P N}}{\frac{1}{a^{2}}+\frac{1}{b^{2}}+\cdots+\frac{1}{n^{2}}}$

dimana :

PX = hujan yang diperkirakan pada stasiun $X(\mathrm{~mm})$

PA,PA..PN= jumlah hujan pada stasiun mengelilingi stasiun hujan $\mathrm{X}(\mathrm{mm})$

$\mathrm{a}, \mathrm{b}, \ldots \mathrm{n}=$ jarak dari stasiun $\mathrm{X}$ ke masing-masing stasiun hujan $\mathrm{A}, \mathrm{B}, \ldots \mathrm{N}(\mathrm{km})$

\subsection{Perhitungan Hujan Rencana}

Dari data hujan maksimum tersebut kemudian dilakukan perhitungan hujan rencana setiap stasiun periode 2 tahun, 
5 tahun, dan 10 tahun. Metode yang digunakan yaitu Metode Gumbel dan Metode Log Pearson Tipe III.

Untuk lebih jelasnya bisa dilihat pada gambar 1.

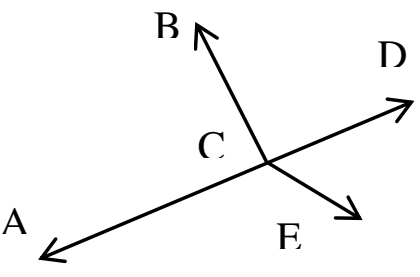

Gambar 1. Posisi Stasiun Hujan

\subsection{Uji Kesesuaian Distribusi}

Pengujian ini dipakai untuk mengetahui apakah suatu data jenis sebaran yang dipilih dapat mewakili dari distribusi statistik sampel data yang dianlisis. Pengujian itu dengan 2 cara, yaitu:

1. Uji Smirnov Kolmogorov

Pengujian ini dilakukan dengan menggambarkan probabilitas untuk setiap data distribusi teoritis dan empiris.

\section{Uji Chi Kuadrat}

Pengujian ini digunakan untuk menguji apakah distribusi pengamatan dapat disamai dengan baik oleh distribusi teoritis.

\subsection{Perhitungan Intensitas Hujan Rencana}

Intensitas hujan setiap stasiun dihitung berdasarkan dari hasil hujan rencana setiap stasiun pula. Metode yang digunakan yaitu Metode Talbot. Persamaan intensitas hujan Metode Talbot adalah sebagai berikut :

$I=\frac{a}{t+b}$

dimana :
I $\quad=$ intensitas hujan (mm/jam)

$\mathrm{t}=$ lamanya hujan (jam)

$\mathrm{a}$ dan $\mathrm{b}=$ konstanta yang besarnya tergantung pada keadaan daerah setempat.

Konstanta $\mathrm{a}$ dan $\mathrm{b}$ dihitung dari metode SDMP Kota Surabaya. Metode ini digunakan karena tidak adanya data intensitas hujan dari lapangan.

\subsection{Penggambaran Pola Intensitas Hujan Rencana}

Dari hasil analisa hujan rencana dan intensitas hujan rencana setiap stasiun kemudian digambar di Peta Kota Surabaya. Penggambaran pola hujan rencana dan intensitas hujan rencana menggunakan metode isohyet. Dalam metode ini dibuatkan garis kontur yang menghubungkan stasiun-stasiun yang mempunyai jumlah hujan rencana dan intensitas hujan rencana yang sama. Kemudian ditambahkan garis-garis kontur yang baru dari interpolasi antara stasiun-stasiun hujan menurut interval yang dihendaki.

\subsection{Perhitungan Intensitas Hujan Rencana di Setiap Kecamatan}

Dari data gambar pola hujan rencana dan intensitas hujan rencana kemudian dihitung berdasarkan masing-masing kecamatan. Untuk menghitung setiap kecamatan maka garis-garis kontur yang melewati kecamatan memakai luas sub area antara 2 garis kontur sebagai faktor pemberat dalam menghitung hujan rencana dan intensitas 
hujan rencana rata-rata di kecamatan tersebut.

\section{Hasil dan Pembahasan}

\subsection{Perhitungan Hujan Rencana Setiap Stasiun}

Data curah hujan yang dipakai untuk analisa adalah data curah hujan maksimum dari stasiun pengamatan curah hujan yang berpengaruh yaitu Gubeng, Gunungsari, Kandangan, Kebon Agung, Kedung Cowek, Keputih, Larangan, Perak, Simo, Wonokromo, dan Wonorejo. Data tersebut diambil berdasarkan waktu yang sama. Data stasiun tersebut jumlahnya berbeda-beda, karena banyak data yang hilang. Data yang sudah dilengkapi berjumlah selama 42 tahun (1973-2014). Setelah dilakukan analisa hujan rata-rata, analisa statistik, dan uji kesesuaian distribusi maka didapatkan hasil curah hujan rencana seperti pada tabel 1 .

\subsection{Perhitungan Intensitas Hujan Rencana Setiap Stasiun}

Dari hasil perhitungan hujan rencana, kemudian dilakukan perhitungan intensitas hujan setiap stasiun. Hasilnya bisa dilihat di tabel 2.

Tabel 1. Curah Hujan Rencana

\begin{tabular}{lccc}
\hline \multicolumn{1}{c}{ Stasiun } & \multicolumn{3}{c}{ Hujan Rencana $(\mathrm{mm})$} \\
\multicolumn{1}{c}{ Hujan } & 2 tahun & 5 tahun & 10 tahun \\
\hline Gubeng & 76 & 114 & 139 \\
Gunungsari & 78 & 118 & 144 \\
Kandangan & 64 & 106 & 134 \\
Kebon & 74 & 102 & 120 \\
Agung & & & \\
Kedung & 49 & 84 & 107 \\
Cowek & 72 & 110 & 134 \\
Keputih & 69 & 105 & 129 \\
Larangan & 69 & 107 & 131 \\
Petak & 92 & 128 & 143 \\
Simo & 78 & 107 & 126 \\
Wonokromo & 75 & 120 & 150 \\
Wonorejo & & & \\
\hline
\end{tabular}

Sumber : Perhitungan

Untuk intensitas hujan periode ulang 2 tahun yang terbesar terjadi di Stasiun Simo yaitu $28 \mathrm{~mm} / \mathrm{jam}$, sedangkan yang terkecil terjadi di Stasiun Kedung Cowek yaitu $15 \mathrm{~mm} / \mathrm{jam}$. Untuk intensitas hujan periode ulang 5 tahun yang terbesar terjadi di Stasiun Simo yaitu $40 \mathrm{~mm} / \mathrm{jam}$, sedangkan yang terkecil terjadi di Stasiun Kedung Cowek yaitu 26 mm/jam.

Tabel 2. Intensitas Hujan Rencana

\begin{tabular}{lccc}
\hline \multicolumn{1}{c}{$\begin{array}{c}\text { Stasiun } \\
\text { Hujan }\end{array}$} & \multicolumn{3}{c}{$\begin{array}{c}\text { Intensitas Hujan Rencana } \\
\text { (mm/jam) }\end{array}$} \\
& 2 tahun & 5 tahun & 10 tahun \\
\hline Gubeng & 24 & 35 & 43 \\
Gunungsari & 24 & 37 & 45 \\
Kandangan & 20 & 33 & 41 \\
Kebon & 23 & 32 & 37 \\
Agung & & & \\
Kedung & $\mathbf{1 5}$ & $\mathbf{2 6}$ & $\mathbf{3 3}$ \\
Cowek & 22 & 34 & 42 \\
Keputih & 22 & 33 & 40 \\
Larangan & 22 & 33 & 41 \\
Petak & $\mathbf{2 8}$ & $\mathbf{4 0}$ & 44 \\
Simo & 24 & 33 & 39 \\
Wonokromo & 23 & 37 & $\mathbf{4 7}$ \\
Wonorejo &
\end{tabular}

Sumber : Perhitungan

Untuk intensitas hujan periode ulang 10 tahun yang terbesar terjadi di Stasiun Wonorejo yaitu $47 \mathrm{~mm} / \mathrm{jam}$, sedangkan yang terkecil terjadi di Stasiun Kedung Cowek yaitu 33 $\mathrm{mm} / \mathrm{jam}$.

Intensitas hujan yang sudah didapatkan dari perhitungan tersebut kemudian diplot di setiap stasiun dalam Peta Kota Surabaya. Dari nilai intensitas hujan tersebut, kemudian dilakukan interpolasi di antara stasiun-stasiun tersebut untuk mendapatkan intensitas hujan yang berada diantara 2 stasiun hujan. Kemudian digambarkan garis isohyet intensitas hujan yang 

ISSN.1907-753X

menghubungkan titik-titik nilai bisa dilihat di gambar 2, 3, dan 4 . intensitas hujan yang sama. Hasilnya

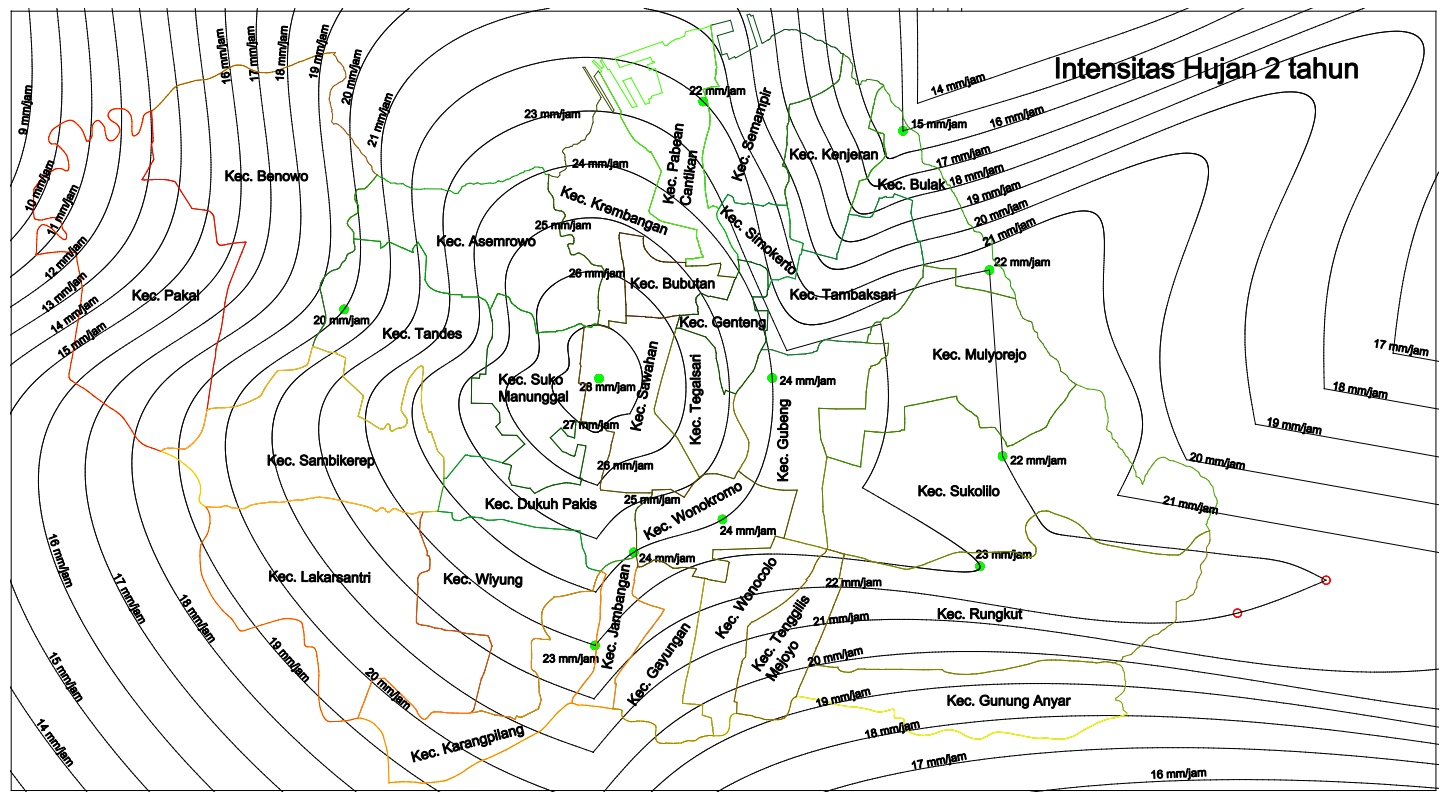

Gambar 2. Pola Intensitas Hujan Periode Ulang 2 Tahun Kota Surabaya

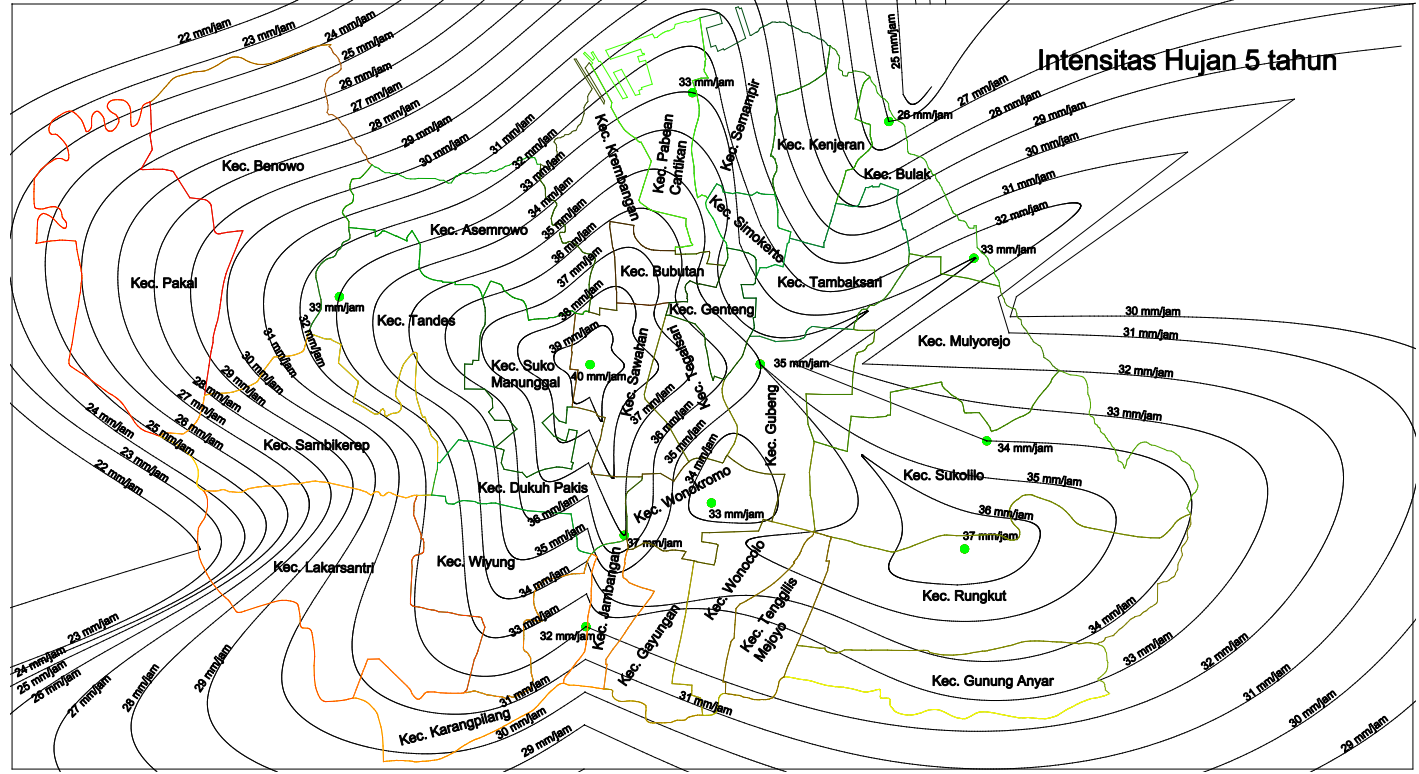

Gambar 3. Pola Intensitas Hujan Periode Ulang 5 Tahun Kota Surabaya 


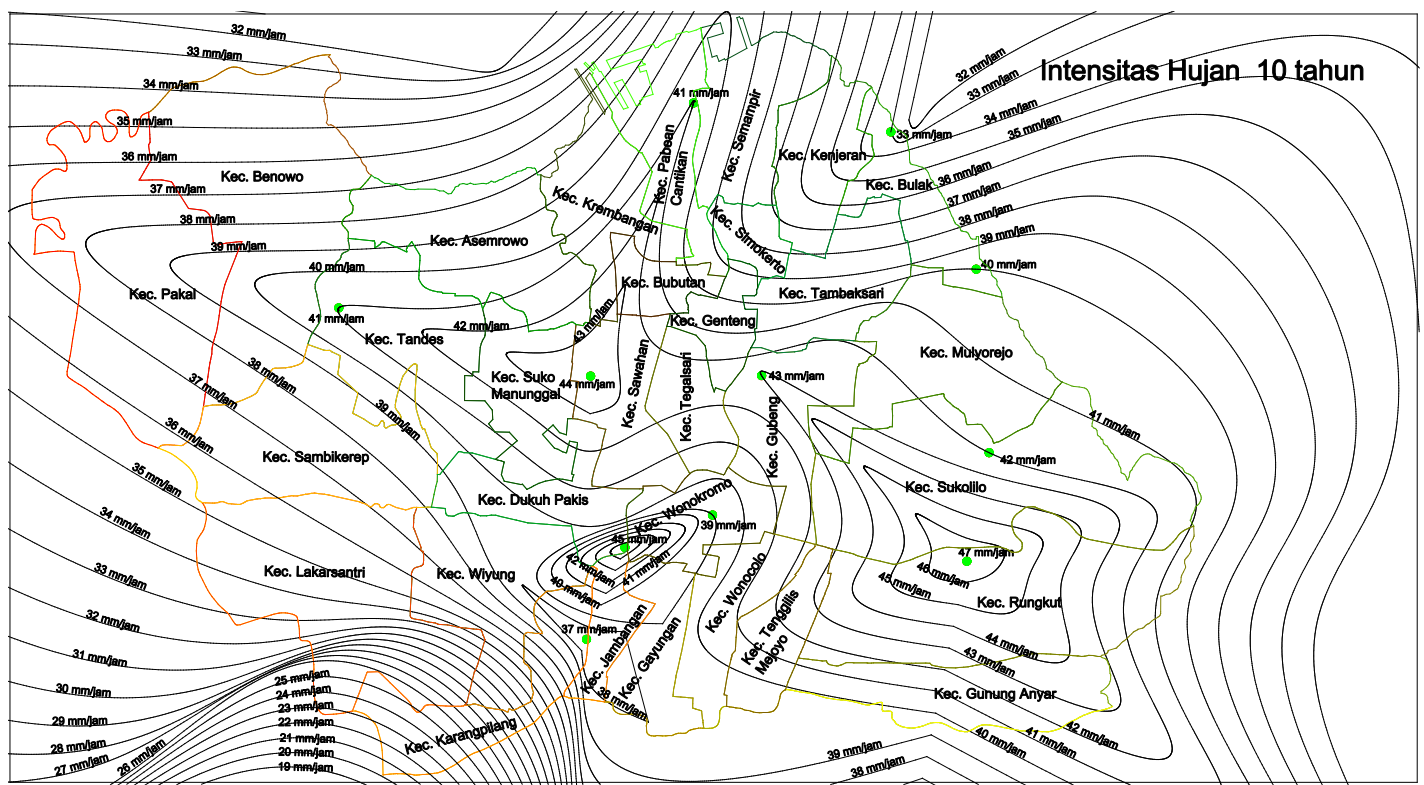

Gambar 4. Pola Intensitas Hujan Periode Ulang 10 Tahun Kota Surabaya

Dari gambar 2, 3, dan 4 dapat dilihat bahwa Intensitas hujan membentuk kontur isohyet yang bervariasi dari berbagai periode ulang. Semakin besar periode ulang maka semakin kecil kerapatan garis isohyet intensitas hujannya.

\subsection{Intensitas Hujan Rencana Setiap Kecamatan}

Perhitungan intensitas hujan rencana setiap kecamatan dihasilkan dari pembacaan peta kontur intensitas hujan Kota Surabaya. Intensitas berikut ini yaitu berupa besarnya intensitas maksimum dan minimum yang melintasi di setiap kecamatan. Untuk lebih mudah dalam pembacaan informasi intensitas hujannya, maka kecamatan-kecamatan tersebut dibagi menjadi beberapa wilayah, yaitu pusat, timur, selatan, barat, dan utara. Untuk lebih jelasnya bisa dilihat di tabel 3.

Dari tabel 3 dapat dilihat bahwa intensitas hujan periode ulang 2 tahun yang terbesar terjadi di Kecamatan Sawahan, sedangkan yang terkecil terjadi di Kecamatan Bulak. Intensitas hujan periode ulang 5 tahun yang terbesar terjadi di Kecamatan Sawahan, sedangkan yang terkecil terjadi di Kecamatan Bulak. Intensitas hujan periode ulang 10 tahun yang terbesar terjadi di Kecamatan Rungkut, sedangkan yang terkecil terjadi di Kecamatan Bulak. Hasil dari analisa ini nantinya bisa digunakan sebagai acuan/ pertimbangan awal dalam perencanaan sistem drainase di wilayah kecamatan tersebut.

\section{Kesimpulan}

Dari hasil analisa dan pembahasan dapat disimpulkan beberapa hal antara lain:

1. Dari pola intensitas hujan rencana 2 tahun, 5 tahun dan 10 tahun menunjukkan semakin besar periode ulangnya maka semakin kecil kerapatan garis isohyetnya. 


\section{ISSN.1907-753X}

Tabel 3. Intensitas Hujan Rencana Setiap Kecamatan

\begin{tabular}{|c|c|c|c|c|c|c|}
\hline \multirow{2}{*}{ Kecamatan } & \multicolumn{6}{|c|}{$\begin{array}{l}\text { Intensitas Hujan Rencana } \\
\text { (mm/jam) }\end{array}$} \\
\hline & \multicolumn{2}{|c|}{$\begin{array}{c}2 \text { tahun } \\
\text { Maks Min }\end{array}$} & \multicolumn{2}{|c|}{5 tahun } & \multicolumn{2}{|c|}{10 tahun } \\
\hline Surabaya Pusat & & & & & & \\
\hline 1. Genteng & 25 & 23 & 36 & 33 & 42 & 39 \\
\hline 2. Tegalsari & 26 & 25 & 38 & 33 & 42 & 41 \\
\hline 3. Bubutan & 26 & 25 & 38 & 34 & 43 & 40 \\
\hline 4. Simokerto & 23 & 21 & 34 & 32 & 39 & 37 \\
\hline \multicolumn{7}{|l|}{ Surabaya Timur } \\
\hline 1. Sukolilo & 23 & 21 & 36 & 33 & 46 & 41 \\
\hline 2. Gubeng & 24 & 23 & 35 & 33 & 43 & 41 \\
\hline 3. Rungkut & 23 & 20 & 37 & 33 & 47 & 41 \\
\hline 4. Tambaksari & 24 & 18 & 34 & 29 & 42 & 36 \\
\hline 5. Mulyorejo & 23 & 22 & 35 & 30 & 43 & 40 \\
\hline 6. Tenggilis & 23 & 19 & 35 & 32 & 43 & 40 \\
\hline Mejoyo & & & & & & \\
\hline 7. Gunung Anyar & 19 & 17 & 34 & 33 & 44 & 40 \\
\hline \multicolumn{7}{|l|}{ Surabaya Selatan } \\
\hline 1. Sawahan & 28 & 25 & 40 & 35 & 44 & 41 \\
\hline 2. Wonokromo & 25 & 23 & 37 & 33 & 45 & 37 \\
\hline 3. Karang Pilang & 24 & 19 & 34 & 30 & 42 & 19 \\
\hline 4. Wonocolo & 23 & 20 & 35 & 31 & 42 & 39 \\
\hline 5. Gayungan & 23 & 20 & 35 & 30 & 42 & 38 \\
\hline $\begin{array}{l}\text { 0. Jambangan } \\
7 \text { Wivung }\end{array}$ & 24 & 22 & 36 & 31 & 44 & 37 \\
\hline 1. wiyung & 25 & 21 & 36 & 32 & 42 & 28 \\
\hline \multicolumn{7}{|l|}{ Surabaya Barat } \\
\hline 1. Tandes & 25 & 19 & 36 & 32 & 42 & 39 \\
\hline 2. Benowo & 13 & 20 & 32 & 24 & 40 & 33 \\
\hline 3. Pakal & 19 & 10 & 29 & 23 & 39 & 35 \\
\hline 4. Sambikerep & 24 & 19 & 24 & 35 & 41 & 36 \\
\hline 5. Lakar Santri & 19 & 23 & 33 & 22 & 37 & 23 \\
\hline 6. Dukuh Pakis & 27 & 24 & 39 & 33 & 45 & 39 \\
\hline \multicolumn{7}{|l|}{ Surabaya Utara } \\
\hline 1. Pabean Cantikan & 24 & 21 & 36 & 31 & 42 & 36 \\
\hline 2. Krembangan & 27 & 23 & 38 & 31 & 43 & 36 \\
\hline 3. Semampir & 23 & 17 & 34 & 28 & 41 & 37 \\
\hline $\begin{array}{l}\text { 4. Suko Manunggal } \\
5 \text { Bulak }\end{array}$ & 27 & 25 & 39 & 36 & 43 & 41 \\
\hline 6 Kenieran & 22 & 15 & 33 & 26 & 40 & 33 \\
\hline $\begin{array}{l}\text { 0. Kenjeran } \\
\text { 7. Asemrowo }\end{array}$ & 20 & 16 & 31 & 27 & 38 & 34 \\
\hline 1. Asemilowo & 27 & 20 & 38 & 30 & 42 & 37 \\
\hline
\end{tabular}

Sumber: Perhitungan

2. Intensitas hujan terbesar periode ulang 2 tahun dan 5 tahun terjadi di Stasiun Simo, sedangkan periode ulang 10 tahun terjadi di Stasiun Wonorejo. Intensitas hujan terkecil periode ulang 2 tahun, 5 tahun, dan
10 tahun terjadi di Stasiun Kedung Cowek.

3. Intensitas hujan terbesar periode ulang 2 tahun dan 5 tahun terjadi di Kecamatan Sawahan, sedangkan periode ulang 10 tahun terjadi di Kecamatan Rungkut. Intensitas hujan terkecil periode ulang 2 tahun, 5 tahun, dan 10 tahun terjadi di Kecamatan Kenjeran.

\section{Daftar Pustaka}

Anggrahini. 1996. Hidrolika Saluran Terbuka. Surabaya: CV. Citra Media.

Br, S. H., 1993. Analisis Hidrologi. Gramedia Pustaka Utama.

Chow, V. T., 1997. Hidrolika Saluran Terbuka. Erlangga: Jakarta.

Loebis, J., 1984. Banjir Rencana untuk Bangunan Air. Jakarta: Badan Penerbit.

Soemarto, C., 1997. Hidrologi Teknik. Surabaya: Usaha Nasional.

Soewarno. 1995. Hidrologi Aplikasi Metode Statistik untuk Analisa Data. Bandung: Nova.

Subarkah, I., 1980. Hidrologi Untuk Perencanaan Bangunan Air. Bandung: Idea Dharma.

Suripin. 2004. Drainase Perkotaan Yang Berkelanjutan. Yogyakarta: Andi.

Suyono. 1993. Pengelolaan Sumber Daya Air. Yogyakarta.

Triatmodjo, B., 2006. Hidrologi Terapan. Yogyakarta: Beta Offset. 
